\title{
Protection, conservation and enhancement of the medieval tower of Vilar and its surroundings, Lousada, Portugal
}

\author{
M. Malheiro \\ Universidade Lusiada, Porto, Portugal
}

\begin{abstract}
The paper discusses both the interdisciplinary study developed between 2005 and 2013 (concerning Architecture, Landscape Architecture, Archaeology and Civil Engineering) and the subsequent design for the protection, conservation and enhancement of the Tower of Vilar ruins and surroundings. The Tower, previously called domus fortis, was built between the $13^{\text {th }}$ and the $14^{\text {th }}$ centuries. As a fortified manor house, it indicated the feudal power over the adjoining territory. The building was in ruins, lost in the middle of uncultivated land at the top of an irrigated valley. It was surrounded by intense urbanization along the pathways snaking the top of the hills that frame the valley. Contemporary interventions in structures for medieval defence tend to focus on the unconditional "enhancement" of the object, or what remain of it, forgetting the territory that they have shaped. The aim of this paper is to show a different form of acting on this heritage. The innovative approach was the characterization of the surroundings of the monument and the public discussions held between all those involved in the organization, planning and definition of that specific territory. The intention was to seek and to articulate new living spaces, in order to help the community introduce new uses and to gather its members around "their" tower. The methodological problems were therefore reversed. Instead of concentrating at the Tower only, the design team focused on the landscape built around it, endowing it with legibility and reinforcing the links it establishes with the tower, while enabling and ensuring a future conservation by the community.
\end{abstract}

Keywords: medieval fortified building, conservation, protection community participation. 


\section{Introduction}

In 2005 the design team won a competition launched by the Rota do Românico, for the intervention project for the ruins of the Tower of Vilar, located in the parish of Vilar do Torno e Alentém, in the municipality of Lousada, northern Portugal. (The Route of the Romanesque, was conceived in 1998, within the municipalities that comprise the VALSOUSA - Associação de Municípios do Vale do Sousa [Association of Municipalities of Vale do Sousa] and extended, in 2010, to the remaining municipalities of the NUT III - Tâmega, thus bringing together in a supramunicipal project a common historical and cultural legacy and is anchored in 58 romanesque monuments.

The action plan contemplated the protection, conservation and enhancement of the building and its surroundings. At that time, the tower was "lost" at the beginning of an irrigated valley, covered by dense vegetation, result of its abandonment for decades. It was raised over a land plateau in the middle of an existing vineyard to the south-west, a woodland area to the north-east, and was surrounded by urban areas to the north-west and north, expanding along traffic routes that run through the tops of the hills, surrounding the Valley.

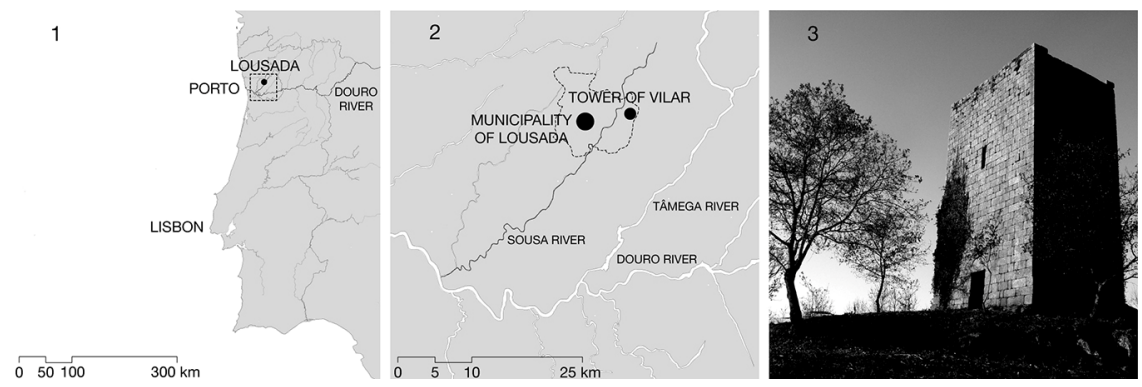

Figure 1: $\quad$ Site location: 1 - Portugal; 2 - Municipality of Lousada; 3 - Tower of Vilar in 2005, before the works.

The aim of this paper is to present the methodology used in a new approach for heritage intervention, as a case study for future interventions. This presentation intents to serve as an exchange of experiences that were obtained during the process that lasted around eight years, beginning with the launch of the competition for the conservation of the Tower, in 2005, and the completion of the second phase of development of the surrounding landscape, in the year of 2013.

The commission held only presupposed the establishment of a program, access and conservation of the Tower, were there was a need to include various disciplines such as landscape architecture, civil engineering, history and archaeology, for comprehensive studies and related diagnostics that provided information about the origins and evolution of the building and its surroundings.

The development of these studies enabled to deepen general knowledge of the building and the place where it was sited, but above all, contributed for the understanding of the role that the Tower exercised in the territory throughout its 
history and how it can contribute, with its past role, in the present and in the future, therefore fulfilling the municipality's and population's expectations for that place.

From these considerations it became clear that the decrepit state of preservation of the Tower was reflected on its surrounding landscape, and the intervention to be carried out should take into account these two realities: the object and its landscape.

The approach to be taken for the conservation of this built heritage could not be governed solely by the paradigm of heritage conservation, because the aim was not to merely protect and classify the object. We could not measure the value of the object only by the value of the past, because if once doing it one would only retain the heritage to a specialised audience.

It was necessary to perform an operation shift approach, moving from the object to the surrounding environment, achieving, with this, the involvement of the local population and political actors for the conservation of a broader entity that could be felt of their own. Hence, this "new" story should recreate a new immaterial world of collective memories, intangible stories, experiences and traditions, allowing heritage to be more accessible to a broader audience, empowering socially participative action for creating a common identity, cultural and political cooperation.

his public widening, especially that which lives with it on a daily basis, allows the assets to become more "present", contributing for the continued maintenance in the future, imbuing other memories for new generations that will use the recreated environment and new spaces. This is about returning to the essence of things, prompting, through direct experience, immersion in place, the vitality of the community itself.

The project's experience will be further reported with the intention to emphasize that intervention on heritage must engage with a wider set of participants, such as the tutelage entities, the municipalities and the local population, and that this only becomes possible when considering the research and interdisciplinary practice, a priori, as a priority.

Apart from several studies and work phases that took place, which will be further debated, it is important to mention that this work was monitored and evaluated by the two national entities that held the heritage umbrella in Portugal (at that time called The Portuguese Institute for the Architectural Heritage (Instituto Português do Património Arquitectónico - IPPAR), and the Central Direction of National Buildings and Monuments (Direcção Geral de Edificios e Monumentos Nacionais - DGEMN). In addition to these, the work was also presented and discussed with the Commission for the Northern Regional Coordination and Development (Comissão de Coordenação e Desenvolvimento Regional do Norte - CCDRN). It was also integrated in the Council of Ministers' Presidency, aimed at the integrated and sustainable development of northern Portugal, the Association of Municipalities of Vale do Sousa (VALSOUSA), the Romanesque Route ( Rota do Românico - RR), the Municipality of Lousada and the Parish of Vilar do Torno e Alentém.

This project was undertaken in three phases: a study phase of the property and its surroundings; the realisation of the conservation project, protection and 
enhancement of the Tower and nearby surroundings; the completion of the valuation of the cleared surroundings, with the creation of the Tower Vilar Park, in two phases.

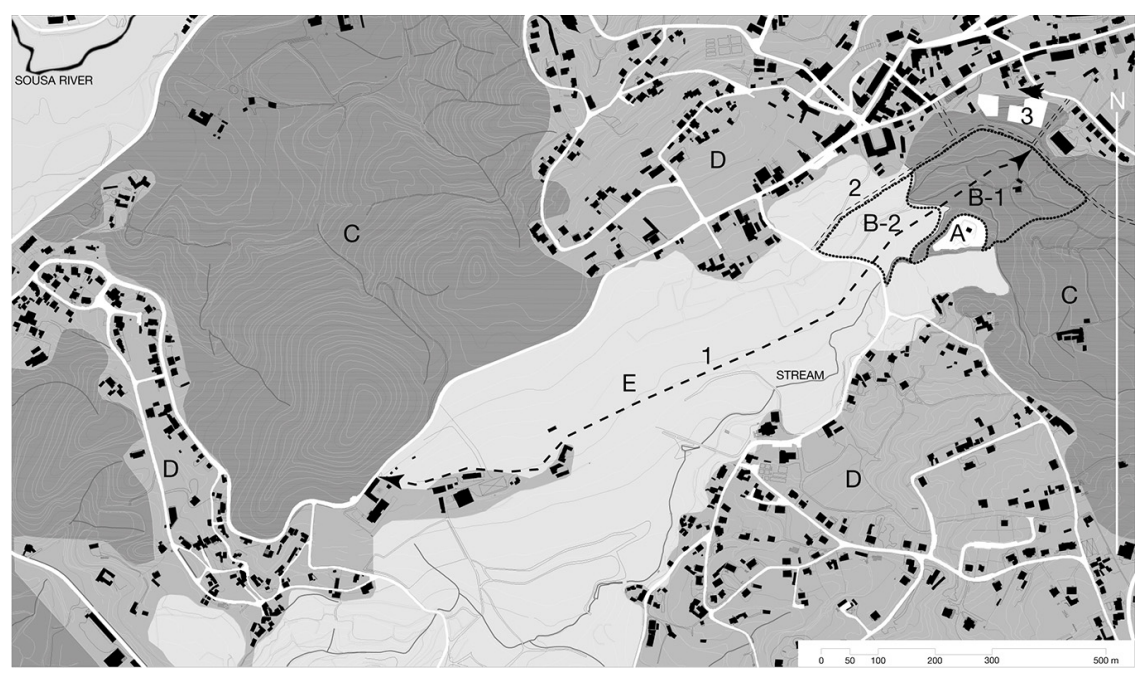

Figure 2: $\quad$ Site plan: A - Tower of Vilar; B-1 - 1st phase of Tower Vilar park; B-2 - 2nd phase of Tower Vilar park; C - Forest zone; D - Diffuse urbanization zone; E - Agricultural zone; 1 - New road not built; 2 - New road built; 3 - New school built.

This paper is organized into three parts and finally, the conclusion. These parts were set in order to understand the various phases and methodology used to perform the transforming operation introduced by the design team. It contains provisional impressions about the project's progress and future directions for research.

\section{The Tower}

Local population was aware of the Tower, "lost" in the midst of a dense bush land, but called it the Moorish Tower, a nickname, in the Northern Portugal, used to name buildings with a remote past and unknown, or little known, history. This coincided with the scarce information available on the Tower and with the fact that it started to ruin at an early stage. The Tower of Vilar is classified as "Public Interest" since 1978 [1], when it was already abandoned and in ruin.

During the first visit made to the object only the four walls that make up the Tower's perimeter were visible, with no remaining structures or secondary elements in wood.

The historical and archaeological studies of the monument indicate the date of construction in the second half of the 13 th century and early 14 th century, "and 
more than a military construction, this building is a symbol of lordly power over the territory" [2].

On the 1258s "inquirições" (administrative enquiries), the place where the Tower is located, called Sancte Marie de Vilar, belonged to D. Gil Martins de Riba Vizela, however, there was no reference to the Tower of Vilar. Only in 1367, there is an indication of the Tower of Vilar in a donation document by the King D. Fernando to Aires Gomes da Silva, and the possession of the tower remained within the same family throughout the $15^{\text {th }}$ century. The construction of the Tower of Vilar was made between 1258 and 1367.

The architectural features of the tower fits into the manorial residence typology, from the Gothic era in northern Portugal, the so-called domus fortis. This type of residence follows a model related to castle architecture, corresponding to a fortified lordly residence, adopted by small lineages, highly motivated in their social rise against the local communities and displaying their pedigree [3]. It had a quadrangular shaped plan, providing a sense of physical and symbolical fortification. The main entrance, for security reasons, it was usually at the first floor. However, in the Tower of Vilar, the front door is on the ground floor, probably because it is more convenient and easy, relegating protection issues to the background.

The Tower of Vilar sums up to 15.70 meters height, sited on a granite rocky outcrop that tops a small elevation. It has a rectangular plan of $9.60 \times 6.90$ meters. The thickness of its walls is about 1.25 meters, and various levels of projecting corbels remained, composing the supports for the roofing frameworks of four levels, with the first level with 3.60 meters, the second with 1.52 meters, the third with 3.48 meters, and the fourth with 4.86 meters.

Its construction is made with exquisite trimmed granite blocks, in pseudoisodome rows, showing the mason's initials in some of the ashlars.

The main door is rectangular, with about 1.60 meters wide, surmounted by a round arch with seven voussoirs, with a plain tympanum. This tympanum has the particularity of the first two voussoirs arch being carved in the stone eardrum itself, revealing a great quality mason work. The existence of five narrow crevices and a door on the second floor, and four crevices and a window on the third, demonstrate that these would probably be the private floors for the lords' residence.

Such as Oliveira tells us, "the construction of a tower not only legitimised the exemption of a land, as it materialised the manor powers, who were not only linked to the rural farm, but also to the exercise of fiscal and judicial powers" [4]. The permanence of the Tower of Vilar until today means that it was tolerated and authorized by the monarchs. Riba Vizela's family enjoyed some influence at court and possessed scattered heritage over the region, being clear that they were an important family. The fine quality of the Tower's construction as well as the various mason's initials existing in some of ashlars, show that there may have been several masons working on the building and its construction probably followed a prescribed project, a circumstance that would not be available to any noble.

The diagnosis made by the Faculty of Engineering of Porto University team, revealed the need for occasional consolidations at the base of the tower, such as a disinfestation of vegetation growing in a substantial part of its structure, requiring 
injecting gravel, lime and sand mortar, in the cracks generated by the same vegetation.

At this time, it became clear that the intervention to be undertaken should consider performing the roofing of the building, this way allowing visitors to climb to the allure, in order to contemplate the landscape carried out to the Tower. Furthermore, it was also necessary to carry out a pedestrian access from the existing street network to the Tower, and consolidate the plateau where it was implanted.

However, at this time, the team felt that it did not make any sense to perform an intervention the Tower of the Vilar, since the direct surroundings were in an abandoned state, and it would be difficult to maintain the Tower secured for a long period of time given that the uncultivated land at its background would "contaminate" the conservation status of the Tower. The intervention would only make sense if it was guaranteed the protection and enhancement of the character of the wider environment, the agricultural valley and the existing wooden area to the south-west and north-east, respectively. This was the next step to undertake.

\section{The surroundings}

"From the tower top one sees the whole valley that extends from Torno to Alentém, which was referential territory for its domain, one of the main links between the Sousa's basin and Tâmega's basin" [5].

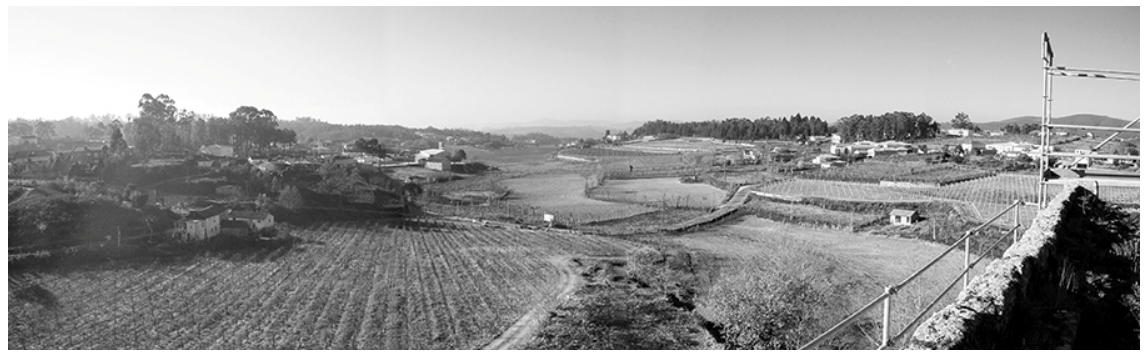

Figure 3: The agricultural valley at the south-west, in 2005.

At this time, in the mid 2005, the design team proposed to conduct a study for the protection and enhancement of the monument for the Rota do Românico, to examine its environment and, above all, so that one could keep closer contact with the tutelage entities and the monuments governing county. This way the team would know the place's future development plans, especially the valley and the hills that surrounded the Tower. This study aimed to define, together with the various entities, a comprehensive strategy that would boost the enhancement of the landscape surrounding the Tower of Vilar. In this process, were still enquired people who lived with that place on a daily basis, one of them being the President of the Parish of Vilar do Torno e Alentém as he presided over the two places that punctuated the beginning and the end of the valley that was intended to be "transformed". 
The diagnosis has allowed us to ascertain that the work area is dominated by an extensive agricultural occupation, due to the natural irrigation of the valley, with the predominance of vine culture (figure 2-E). At the higher elevation terrains, and where soil is poorer, there predominates wood land, with the maritime pine and eucalyptus. The tall growing vine and some plane trees serpent the valley alongside watercourses.

At the top of the hills, where the main roads exist, single family housing projects proliferate along small forest and trees masses, at mid slope, therefore strengthening and support is necessary to enhance the monument's surrounding environment. In addition, a few high-rise buildings of multifamily housing appeared within vicinity of the Tower, at the north and north-east. The collaborating authorities were notified and the team raised the awareness that this "aggression" to the context of the surrounding territory was symptomatic of the excessive urbanization being performed, and also highly desirable to the extent of diffuse and standardizing urbanization. Hence defining ruling principles is necessary and adequate for the surrounding monument's context protection and enhancement, which still showed signs of ancestral occupation that should be preserved and passed on to generations to come.

The municipality of Lousada was engaged in this process, using the team's considerations on their urbanisation plans. At the same time, it was realised that Special Protection Zone (ZEP) should be created for the monument, embracing the whole valley. This was also sent to the authority of legally protected cultural heritage areas, the IPPAR, although it still has not been ratified.

Afterwards, the design team tried to understand which kind of facilities were to be was projected for that place, finding out that a road was planned to be built along the valley's axis in south-west - north-east direction (figure 2-1) and one school center (figures 2-3) at north-east of the Tower. One of the planned facilities would undermine the whole the team's intervention plan, with the creation of the road, contributing for extending the urbanized area, breaking all positive unity already identified.

The school center, however, could be used as an argument to add other positive land units, and above all to strengthen the cohesion of the landscape surrounding the Tower.

Therefore, we justified the negative aspects that a new street would have on the territory, contributing for the standardization of the territory based on diffuse urbanization, and this argument was accepted by the municipality, which has put aside its implementation. This was one of the hardest battles on this work, but also the most important one, given the negative effect it would have had on the land. Later, a new route was made at the north-west of the Tower (figure 2-2), but only a portion of the valley, along the urbanized area, and it had no negative impact.

Regarding the school center, it was used to start another project: the creation of a park in the Tower surrounding area (figure $2-\mathrm{B} 1-\mathrm{B} 2$ ), an uncultivated land with forests of infesting species. Having previously undertaken the diagnosis, the argument was to consider the school center's adjacent space as a Leisure Area to the school itself that local people could also enjoy. 
This proposal was also accepted by the municipality and cherished by the Parish. This was an extremely important factor for the space's unity by rearranging this area into a bocage landscape, featured in medieval times, with the saltus, the forest area, at the beginning of the valley, at north-east, and the ager, the excellence space for land harvesting, at south-west, making up the entire valley.

After ensuring the stabilisation and enhancement of the environment, the team engaged of the Tower conservation plans, regarding the strength the park would create for the consolidation and optimisation of the entire surrounding areas.

\section{The project}

The conservation and enhancement plan for the Tower of Vilar was the actual response to the previous constructive diagnosis, and definition of a program that would respond to the concerns of the population and the Rota do Românico, which took the responsibility to make use of the property.

The program consisted in achieving the two main objectives identified in the studies previously performed: to provide access to the top of the building in order to observe the Tower's transformed landscape; and to protect the stone structure by building a rooftop. Thus, a wooden structure was executed, supported on the existing stone corbels, which contemplated wood levels and stairs to access the top of the Tower.

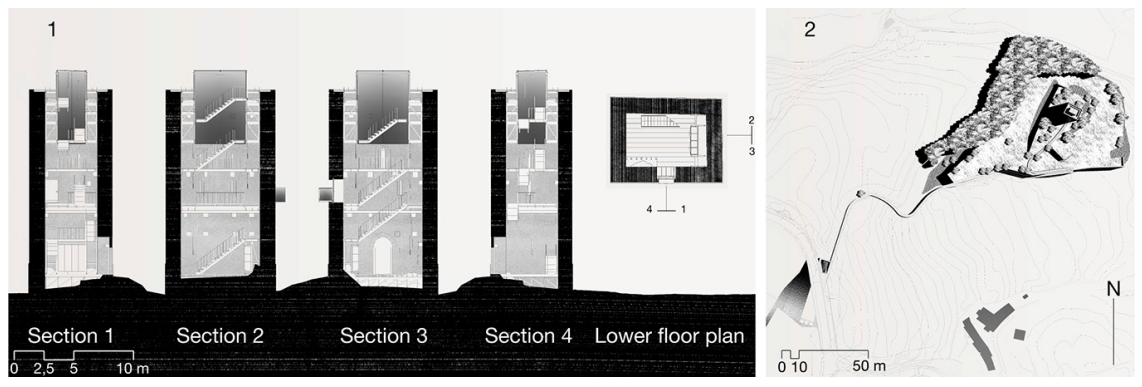

Figure 4: 1 - Interior project of Tower of Vilar; 2 - surrounding environment project of Tower of Vilar.

The spaces created allow the realisation of various exhibition events related to the Rota do Românico and the region, having served since its inauguration as its Interpretation Center and exhibition space, such as that which is being held presently, with the exhibition of the "transformation" project of another tower in the area, designed by an architectural student, under my supervision.

In the surrounding environment, the walls that make the Tower's plateau were stabilised; pedestrian solid ground footpaths were made to provide access to the Tower, landscaping and execution of support furnishing such as seats and dustbins. These works were developed between the years of 2005-2006, initially, and 2012, in a second phase, corresponding to the creation of a parking area along the main road and the betterment of water sources located there. 
In parallel, the Municipality of Lousada initiated the acquisition of vacant land surrounding the Tower, for the creation of the Tower of Vilar's park. The execution work started out in 2009, with the second phase being complete in 2013 (figure $2-\mathrm{B} 1$ and $\mathrm{B} 2$, respectively).

This project was carried out by the municipality of Lousada, and was accompanied by an element of the Romanesque Route, who was part of the design team at the beginning of this whole process, meaning the sharing of the same objectives. Thus, the footpaths' treatment, as well as the furnishings placed at this stage, corresponded to the same process used to characterise the Tower's adjacent surrounding, fulfilling the aim of unifying the whole space.
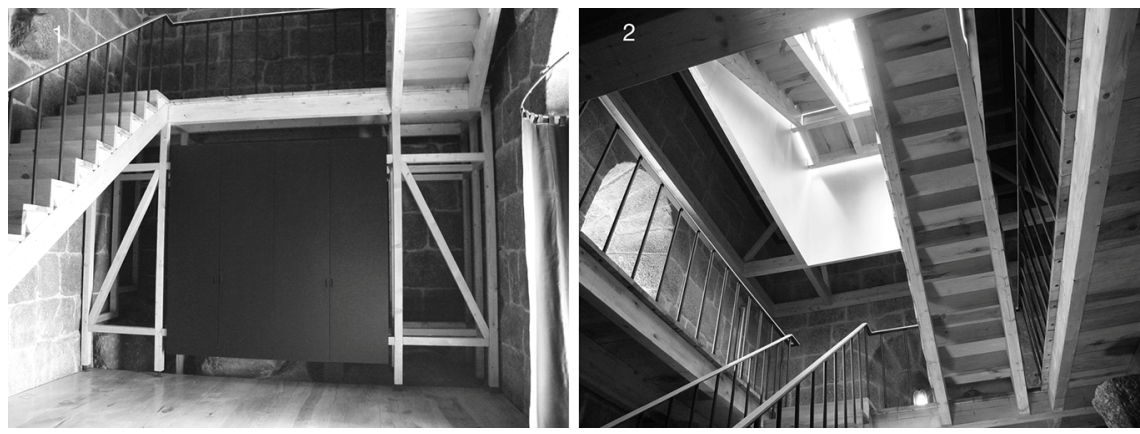

Figure 5: Tower of Vilar inside after the works; 1 - Lower floor; 2 - Skylight rooftop.
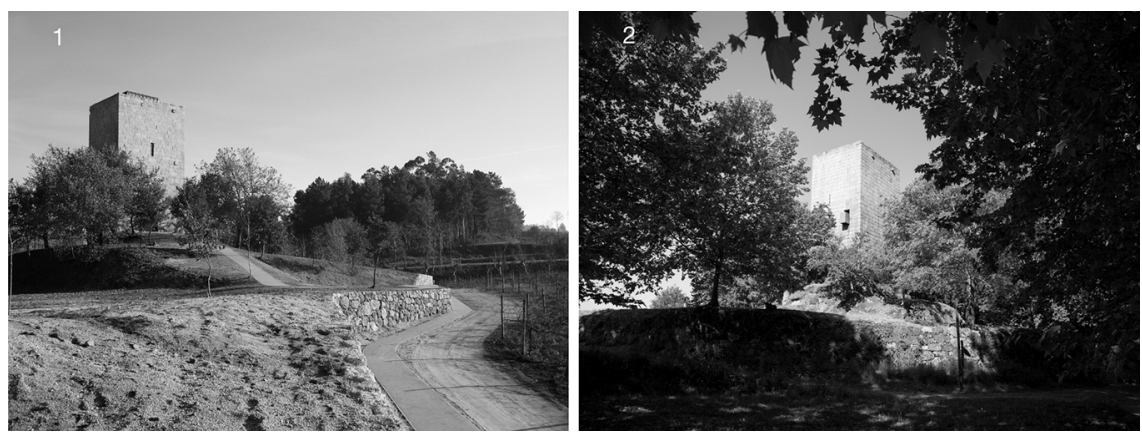

Figure 6: Tower of Vilar outside after the works; 1 - Walls of the motte, and pedestrian solid ground footpaths after the works, 2006; 2 - View of the Tower after the works of the Tower of Vilar Park, 2014.

Furthermore, autochthonous vegetation species were preserved, such as oaks, poplars and plane trees and some fruit trees such as walnut, cherry, quince, pear, apple and fig tree.

This leisure space consisted on the rehabilitation of existing structures, such as small water dams and rural buildings, with footpaths interconnecting with the paths that we created to access to the Tower of Vilar, preserving the natural terrain morphology. Today, the park consists of approximately 5.5 acres of land. 
This expansion of the park will allow for the possibility to build on the new street created to replace the road proposed in 2005, now smaller set along the hillside of the urbanised area, linking the school center to the road that connects to the Tower of Vilar, safeguarding the expansion of the diffuse urbanisation, as pointed out by the team.

\section{Conclusions}

As is it readily seen, this process was performed as any architectural project starting with a blank sheet. The design team drew multiple lines throughout the process to conform to an idea. There was the need to bear in mind the concepts that were at the outset of that building, and at the same time aiming to develop those into other ones, concerning the contemporary reality of that place. This was the process, and although they saw new realities emerge, these were the ones with which the team had to work, building the awareness that roles should be inverted.

The Tower's placement over that place exhibited its "lord" possession, relegating any defensive position to a second plan, leading us to consider that the surrounding land was organised that way because it had been created for the Tower, because the "foundations of the 'territory' are due to the union of man and space, civilized space of that which, through its work, takes hold of it, therefore, containing the history of men who made it and live in it" [6, p. 153]. That is, "the relationship between the monument and its surroundings, would be in the sense of the relationships that the monument, the possible place above all else, could establish with the morphological and geographical conditions of the land, as an adaptation to the natural landmark, making visible the entire geographic surrounding" [6, p. 169].

The Tower of Vilar dominated the valley for much of its existence, having various manifestations of that reality. However, the new concept that was being sketched postulated the principle of the need to invert roles, putting the valley to exercise dominion over the tower, combining ancestral agricultural activities, still taking place, with new uses related to leisure, with special benefits for the body and soul, via the wood landscape rehabilitation area.

Reflecting on the development of this process, in the period of roughly eight years, we would say that the chance of accomplishing a school center in the vicinity of the Tower was a fortunate achievement. However, a clear answer at the time, regarding the advantage of using uncultivated land that existed to make the school's playground, arose spontaneously. This was an effort from conversations and interdisciplinary studies of the design team, which had pointed the obvious need to pass on some information to the local population, reinforcing that the Tower of Vilar was part of their past and it was extremely important for conservation that was they could be part of his present and future. It is particularly important to pass this message to the younger population of the region, since it will be up to them to ensure the future maintenance of the Tower.

Thus, the new Tower Vilar Park highly contributes to the perduration of the monument that gives name to the place, because it conforms it, allowing 
the community to live with its "tower", providing a constant alert for the need to preserve it. The central objective of this work was completed.

We conclude that this operation was no longer a conservation operation, becoming a transformation operation, because, as Alves Costa mentioned, it refreshes the existing, "overlaying or changing languages and styles, offering new contents, without changing the pre-existing, 'a simplicity posture of the ancient master masons', re-reading the story with the aim of clarifying it".

The intervention carried out the result of a "historical interpretation of the various stages of monuments, including contemporary ones, where the new works are integrated into a heritage enhancement process that is understood as collective, 'using the real, which contains the past and desired future, one finds the rule from the existing, case by case and always legible in each work" [7].

Like other authors, who view the intervention in heritage as an act of transformation, we believe that this case study began with the assumption of the need to involve issues of past, present and future. The existing presented clues for the intervention to be undertaken, in the sense that is stressing by Diedrich when referring to this "art of transformation", asserting, as we try to proceed, that reality "becomes the main driver and the project a hermeneutical agent that privileges the concept of novelty, in the sense that it focuses more on creating new perceptions about the existing than in ex nihilo creation of new objects" [8].

\section{References}

[1] IIP - Imóvel de Interesse Público, Decreto n ${ }^{\circ}$ 95/78, DR, $1^{\text {a }}$ série, n. ${ }^{\circ} 210$ de 12 setembro 1978.

[2] Malheiro, M. - A intervenção arquitectónica na Torre de Vilar. In Actas do I Encontro de Arqueologia das Terras de Sousa. Oppidum - Revista de Arqueologia, História e Património. Lousada: Câmara Municipal de Lousada. Número Especial, 2008, pp. 283-290.

[3] Almeida, C. A. F. and Barroca, M. J. - O Gótico. História da Arte em Portugal. Lisboa: Editorial Presença, 2002, pp. 124-128.

[4] Oliveira, A. M. - "Ocupação senhorial do Vale do Sousa: dois exemplos em estudo". In Actas do I Encontro de Arqueologia das Terras de Sousa. Oppidum - Revista de Arqueologia, História e Património. Lousada: Câmara Municipal de Lousada. Número Especial, 2008, pp. 257-281.

[5] Malheiro, M. et al. - "Torre de Vilar". In Estudo de Valorização e Salvaguarda das Envolventes aos Monumentos da Rota do Românico do Vale do Sousa: $2^{a}$ Fase. Porto: [s.n.], 2005. Vol. II, p. 252.

[6] Malheiro, M. , A presença da Arquitectura. A arquitectura Românica do vale do rio Sousa, Tesis Doctorale, Universidad de Valladolid. Escuela Técnica Superior de Arquitectura, Valladolid, 2012, Vol. I.

[7] Costa, A. A., A arte de construir a transformação. Património/Estudos, IPPAR - Instituto Português do Património Arquitectónico, Lisboa, 2002, (3), pp. 124-128.

[8] Diedrich, L., Entre a tabula rasa e a museificação. Paisagem e Património. Aproximações Pluridisciplinares, Equações de Arquitectura, Dafne Editora, Chaia, Universidade de Évora, Porto, 2013, pp. 83-107. 